\title{
Preparation of Biodegradable Thermo-responsive Polyaspartamides with $N$-Isopropylamine Pendent Groups (I)
}

\author{
Jong-Rok Moon and Ji-Heung Kim \\ Department of Chemical Engineering, Polmher Technologv Institute, Sunghyntivan Lniversity,

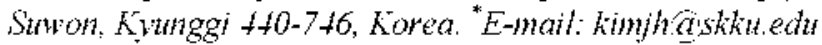 \\ Recerved August 7, 2006
}

\begin{abstract}
Novel amphiphilic. thermo-responsive polyaspartamides which showed both LCST (lower critical solution temperature), and sol-gel transition were prepared and characterized. The polyaspartamide derivatives were șinthesized from polysuccinimide. the polycondensate of aspartic acid monomer. via successive mucleophilic ring-opening reaction by using dodecylamine and $N$-isopropy lethylenediamine (NIPEDA). At the intermediate composition ranges. the dilute aqueous solution exhibited a thermally responsive phase separation due to the presence of LCST. The phase transition temperature was controllable by changing the content of pendent groups. In addition. a physical gelation i.e. the sol-gel transition was observed from the concentrated solutions. which was elucidated by dynamic viscoelastic measurements. These novel injectable and thermo-responsive hydrogels have potential for various biomedical applications such as tissue engineering and current dnig delivery system
\end{abstract}

Key Words : Themno-responsive poly mer, Polyaspartamide. Anphiphilic. LCST. Sol-gel transition

\section{Introduction}

Stimuli-responsive polymers have attracted great interest in the field of novel dnug delivery. cell encapsulation. and tissue engineering due to their promising potential. Among them. temperature and $\mathrm{pH}$ responsive systems have widely been investigated ${ }^{1.2}$ Poly ( $N$-isopropyl acrylanide). PNIPAAm. is one of the most typical thermosensitive polymers. which undergoes a rapid and reversible hydration-dehydration change through the LCST(lower critical solution temperature). PNIPAAm. NIPAAm-containing copolymers. and the hyddrogels have been widely applied to controlled dng delivery and various bio-related applications

Recently injectable polymeric hydrogels are becoming very attractive in their applications such as novel drug delivery and tissue engineering field. The polymers are loaded with bioactive molecules or cells in an aqueous solution and in-situ turn into physically crosslinked hydrogels by external stimuli such as temperature. $\mathrm{pH}$ and light. Among them. thermo-responsive hydrogels have been extensively investigated which can undergo rapid transformation from a liquid form to a gel state at body temperature without any additives. Most of the reported injectable hydrogels. however. are non-biodegradable and this may limit their use in biomedical field.

Polypeptides and related synthetic poly(amino acid)s have become important because of their desirable properties such as biocompatibility and biodegradability, which are useful for various bio-related industries. Poly(aspartic acid). PASP. is one of water-soluble and biodegradable polyamide. which can be produced from the hydrolysis of polysuccinimide (PSI) the polycondensate of L-aspartic acid monomer. Polyc $(N$-2-hýdroxyethyyl-DL-aspartamide). PHEA is another derivative polymer. obtained by coupling PSI with ethanol- amine, which has been proposed as a potential plasma extender and material for drug delivery. such as macromolecular prodrugs, polymeric micelles. and nanoparticles. The attachment and chenical modification of pendent groups either by the aminolysis reaction to PSI or by the secondary reaction through hydroxyl or carboxylic groups of the PASP and PHEA can provide a variety of biodegradable functional polymers with specific properties. Very extensive studies on this class of material have been carried out by Gianmona et al. and other groups. ${ }^{3-8}$ Also. Watanabe et al reported some thermosensitive systems based on polyaspartamide derivatives recently: ${ }^{9.10}$

In this work. we prepared novel amphiphilic graft copolymers based on polyaspartamides containing $N$-isopropylamine moiety to identify materials which showed both LCST behavior and sol-gel transition in aqueous solution.

\section{Experimental}

Materials. L-aspartic acid (98+\%). o-phosphoric acid $(98 \%) . N$-isopropylethylenediamine (NIPEDA 98\%). dodecylamine (laurylamine, LA 98\%), N,N-dimethylformamide (DMF. anhydrous 99.8\%) were purchased from Aldrich Chemical Co. and used as received. Diethylether (99\%) was obtained from DaeJung Chemical Co. (Korea). All of the other chemicals purchased were of high quality and used without purification.

Measurements. 'H-NMR spectra were recorded on a Bruker AMX-500 spectrometer using $\mathrm{D}_{2} \mathrm{O}$ and DMSO-do as the solvent. The FT-IR spectra were obtained on a PerkinElmer FT-IR spectrometer (Model SPECTRUM 2000). The LCST of the polymer in phosphate buffer solution (PBS. $\mathrm{pH}$ 7.4) or distilled water was measured by a UV-visible spectrometer (Biochrom Libras22) equipped with a cell holder and 
temperature controller at $1{ }^{\circ} \mathrm{C} / \mathrm{min}$. The change in transmittance as a function of temperature was observed from a visible source at $500 \mathrm{~nm}$ and the polymer concentration was $\mathrm{l} \mathrm{wt} \%$. A dynamic light scattering instrument (DLS. Brookhaven. BI-2000AT. USA) equipped with a temperature controller and $\mathrm{Ne}-\mathrm{He}$ laser was used to measure the average diameter and particle size distribution of polymeric spheres in distilled water (concentration $1 \mathrm{w} t \%$ ). The polymer product was magnetically dispersed in distilled water and then filtrated using $0.45 \mu \mathrm{m}$ pore-sized filter paper to remove oversized materials. The light intensities scattered from the polymeric spheres were measured at the angle of $90^{\circ} \mathrm{C}$. The viscoelasticity of the polymer solutions were measured using a stress-controlled rheometer (AR2000 TA-Instrument. USA) with a parallel plate with a diameter $40 \mathrm{~mm}$ at a heating ratio of $1{ }^{\circ} \mathrm{C} / \mathrm{min}$ and a frequency of $1.0 \mathrm{~Hz}$.

Synthesis of Polysuccinimide (PSI). L-aspartic acid (20 g) and $o$-phosphoric acid $(20 \mathrm{~g})$ were charged into a roundbottom flask and stirred under reduced pressure at $200^{\circ} \mathrm{C}$ for $5 \mathrm{~h}$. The reaction mixture was then cooled and DMF was added to dissolve the product. The resulting solution was precipitated in excess water and the precipitate was washed several times with water to remove the residual phosphoric acid. The final product was dried at $80^{\circ} \mathrm{C}$ under vacuum. The prepared PSI had a reduced viscosity of $0.52 \mathrm{dL} / \mathrm{g}$ in DMF. The molecular weight was estimated to be approximately $160.000 \mathrm{Da}$ as calculated from an empirical equation relating the solution viscosity to the molecular weight. ${ }^{l 1}$

Synthesis of PolyAspAm(NIPEDA). $0.5 \mathrm{~g}$ of PSI was dissolved in $5 \mathrm{~mL}$ DMF in a three-neck round flask at $25^{\circ} \mathrm{C}$. and an equimolar amount of NIPEDA was then added dropwise at $0^{\circ} \mathrm{C}$. This mixture was stirred at room temperature for $24 \mathrm{~h}$, and then the solution was precipitated into 10 fold ethylether. The filtered precipitate of the Poly'AspAm (NIPEDA) was washed with flash ethylether for several time and dried at $25^{\circ} \mathrm{C}$ in vacuum (yield $95 \%$ ).

${ }^{1} \mathrm{H}-\mathrm{NMR}(500 \mathrm{MHz}, \mathrm{D}=\mathrm{O}): \delta 2.5-3\left(\mathrm{~m}, 5 \mathrm{H} . \mathrm{CH}-\mathrm{CH}_{2}-\mathrm{CO}-\right.$ $\left.\mathrm{NH}-\mathrm{CH}_{2}-\mathrm{CH}_{2}-\mathrm{NH}-\mathrm{CH}-\left(\mathrm{CH}_{3}\right)_{2}\right), 4.56-4.7$ (m. IH. NH-CH$\left.\mathrm{CO}-\mathrm{CH}_{2}\right), 3.2-3.4$ (br. $2 \mathrm{H}$. NH- $\mathrm{CH}_{2}-\mathrm{CH}_{2}-\mathrm{NH}-\mathrm{CH}-\left(\mathrm{CH}_{3}\right)_{2}$ ), $0.9-1.2$ (br. $6 \mathrm{H}$. NH-CH- $\left.-\mathrm{CH}_{2}-\mathrm{NH}-\mathrm{CH}-\left(\mathrm{CH}_{3}\right)_{2}\right)$, Figure la.

Synthesis of Amphiphilic PolyAspam(LA/NIPEDA). A typical procedure to prepare amphiphilic copolymer is described as follows: $0.5 \mathrm{~g}$ of PSI was dissolved in $5 \mathrm{ml}$ DMF in a three-neck round flask equipped with a nitrogen inlet and outlet. $45 \mathrm{~mol} \%$ (based on succinimide) of LA was then added dropwise at $0^{\circ} \mathrm{C}$. Subsequently. the reaction flask was placed in a water bath controlled at $70^{\circ} \mathrm{C}$ and stirrer for $6 \mathrm{~h} .55 \mathrm{~mol} \%$ of NIPEDA was then slowly added to the solution and stirred at $30^{\circ} \mathrm{C}$ for $24 \mathrm{~h}$. The final solution was then precipitated into a 10 -fold ethylether. The filtered precipitate of the PolyAspAm(LA/NIPEDA) was dried at 25 ${ }^{\circ} \mathrm{C}$ in vacuun (yield $74 \%$ ).

${ }^{1} \mathrm{H}-\mathrm{NMR}\left(500 \mathrm{MHz}, \mathrm{DMSO}-\mathrm{d}_{6}\right): \delta 2.5-3(\mathrm{~m}, 5 \mathrm{H}, \mathrm{CH}-$ $\left.\mathrm{CH}_{2}-\mathrm{CO}-\mathrm{NH}-\mathrm{CH}_{2}-\mathrm{CH}_{2}-\mathrm{NH}-\mathrm{CH}-\left(\mathrm{CH}_{3}\right)_{2}\right), 4.5-4.7(\mathrm{~m}, \mathrm{lH}$. $\left.\mathrm{NH}-\mathrm{C} \mathrm{H}-\mathrm{CO}-\mathrm{CH}_{2}\right), 3.2-3.4$ (br. $2 \mathrm{H}, \mathrm{NH}-\mathrm{CH}_{2}-\mathrm{CH}_{2}-\mathrm{NH}-\mathrm{CH}-$ $\left.\left(\mathrm{CH}_{3}\right)_{2}\right), 0.92-\mathrm{L} .12$ (br. $\left.6 \mathrm{H}, \mathrm{NH}-\mathrm{CH}_{2}-\mathrm{CH}_{2}-\mathrm{NH}-\mathrm{CH}-\left(\mathrm{CH}_{3}\right)_{2}\right)$, 1.32-1.47 (br, 2H. NH- $\left(\mathrm{H}_{2}=\left(\mathrm{CH}_{2}\right)_{(i)}-\mathrm{CH}_{3}\right), 1.11-1.27$ (br.

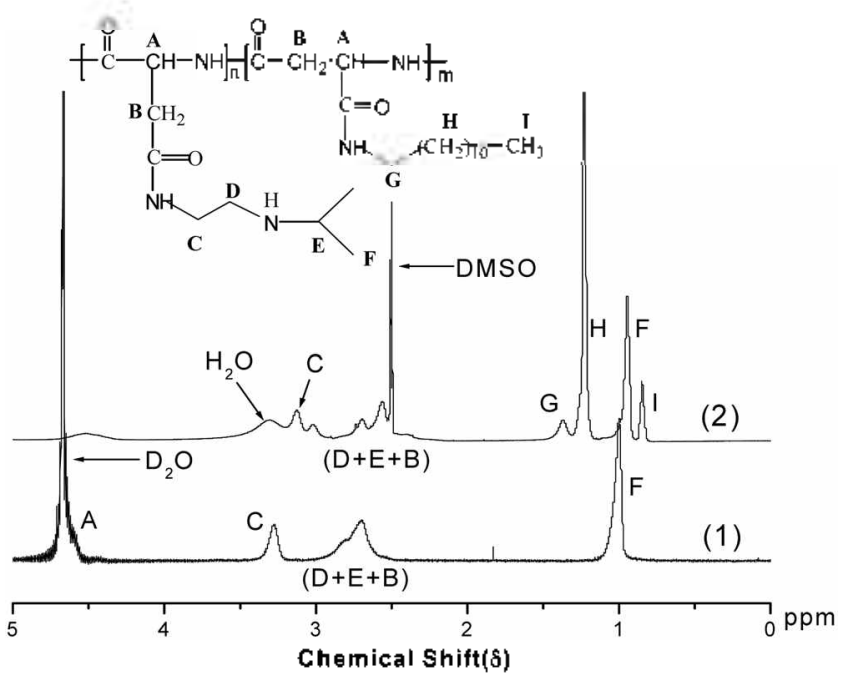

Figure 1. 'H-NMR spectra of PolyAspAm(NIPEDA) (1) and PolyAspAm(LANIPEDA) (2).

$\left.10 \mathrm{H}, \mathrm{NH}-\mathrm{CH}_{2}-\left(\mathrm{CH}_{2}\right)_{10}-\mathrm{CH}_{3}\right), 0.8-0.76$ (br, 3H. NH-CHב$\left.\left(\mathrm{CH}_{2}\right)_{1(1-} \mathrm{CH}_{3}\right)$. Figure $\mathrm{lb}$.

\section{Results and Discussion}

The preparation of polysuccinimide. the precursor polymer, has been well described in literature. ${ }^{11,12}$ Novel amphiphilic polyaspartamide derivatives with $N$-isopropylamine pendant were sy'nthesized from PSI via successive nucleophilic ringopening reaction by using laurylamine (LA) and $N$-isopropylethylenediamine (NIPEDA).<smiles>CCCNC(=O)C(CC(C)(C)C)NC(=O)CC(C)(C)N1CC(C)(C)CC1=O</smiles>

PSI

PolyAspAm(LA)

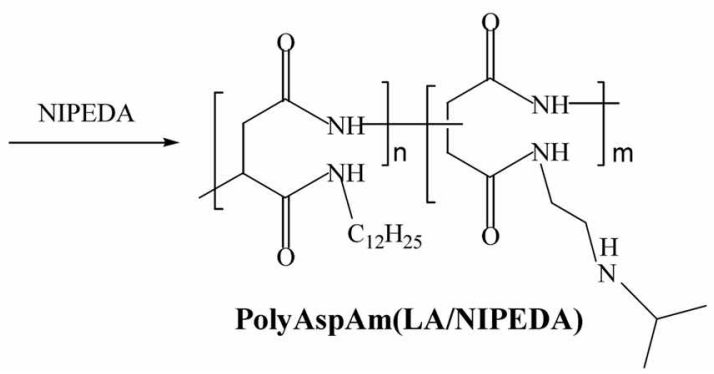

The reaction was carried out in anhydrous DMF in which the succinimide group of PSI was quantitatively reacted to form $\mathrm{N}$-substituted aspartamide unit. The composition of the prepared copolymer was analyzed by ${ }^{1} \mathrm{H}-\mathrm{NMR}$ spectroscopy. Figure I shows the ${ }^{1} \mathrm{H}-\mathrm{NMR}$ spectra of the Poly AspAm (NIPEDA) (1) and PolyAspAm(LA/NIPEDA) (2) copolymer. As shown in Figure 1, the proton peaks $\mathrm{C}$ and $\mathrm{F}$ were 


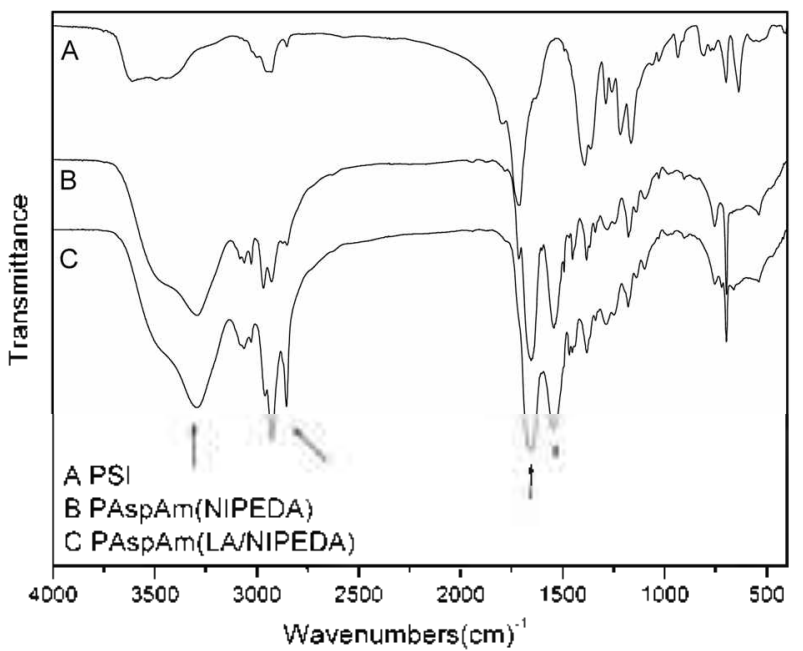

Figure 2. FT-IR spectra of PSI (A), PolyAspAm(NIPEDA) (B), and PolyAspAm (LANIPEDA) (C).

assigned to the NIPEDA pendants, and the $\mathrm{G} \mathrm{H}$, and I peaks were related to methylene and teminal methyl protons of the LA pendants. The composition of each group in the polyaspartamide copolymer was determined from the integration ratio between peak $\mathrm{F}$ and $\mathrm{I}$.

Figure 2 shows the FT-IR spectra of PSI (A). PolyAspAm (NIPEDA) (B) and Poly'AspAm (LA/NIPEDA) copolymer (C). Both spectrum $B$ and $C$ show characteristic strong bands at $1649 \mathrm{~cm}^{-1}$ (amide I), $1545 \mathrm{~cm}^{-1}$ (amide II) and 3305 $\mathrm{cm}^{-1}(-\mathrm{NH}-)$ corresponding to the aspartamide backbone structure. and the band at $2950 \mathrm{~cm}^{-1}$ corresponding to the $\mathrm{CH}_{2}$ stretching appeared after the aminolysis reaction between PSI and NIPEDA. On the other hand. Spectrum C shows stronger alky lene absorption band at $2950 \mathrm{~cm}^{-1}$ due to the introduction of LA moiety. FT-IR and ${ }^{1} \mathrm{H}-\mathrm{NMR}$ analy ses indicated that the polyaspartamide derivative polymers had been prepared successfully from the aminolysis reaction of PSI.

Thermal analysis of the Poly'AspAm(NIPEDA) and Poly'AspAm(LA/NIPEDA) under nitrogen showed Tg's of the polymer at around $40^{\circ} \mathrm{C}$, as determined by the mid-point of the baseline change in DSC. These polymers were stable up to $c a .200^{\circ} \mathrm{C}$ without any weight loss as deternined by the TGA in nitrogen.

At the intermediate composition ranges of Poly AspAm (LA/NIPEDA) copolymer. the dilute aqueous solution exhibited a thermally responsive phase separation. The temperature dependence of light transmittance of $1 \mathrm{wt} \%$ aqueous solution at $500 \mathrm{~mm}$ is shown in Figure 3. Polymer A-C exhibited a relatively sharp phase separation in the temperature range from 25 to $45^{\circ} \mathrm{C}$ due to the presence of LCST in this particular system. As the content of hydrophobic pendant (LA) increased the transition temperature decreased linearly. At the LA content over $45 \mathrm{~mol} \%$. the polymers were found to be insoluble in water at room temperature. In phosphate buffer saline (PBS. $\mathrm{pH}$ 7.4) solution the transition temperature was shifted to a higher temperature with different degrees as shown in the Figure 3.

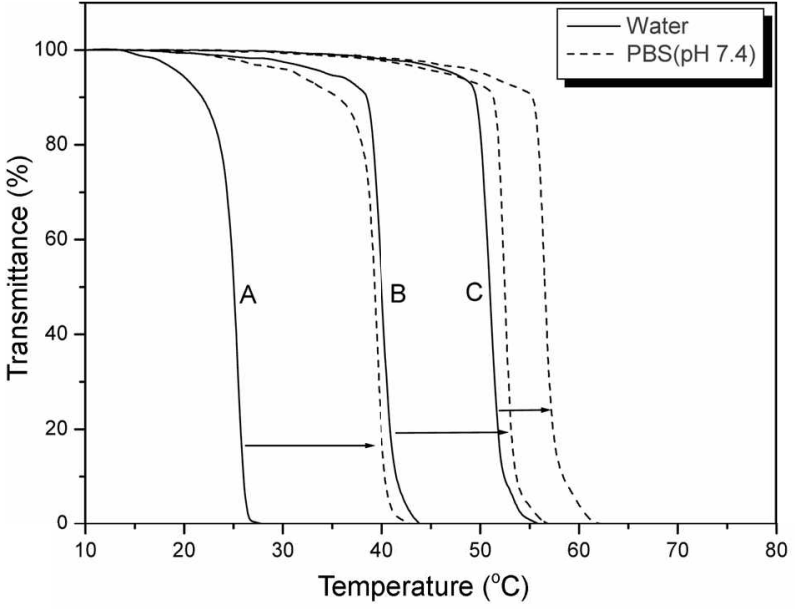

Figure 3. LCST behavior of amphiphilic copolyaspartamides. (LA content in mol\%: $A=41: B=39: C=36$ )

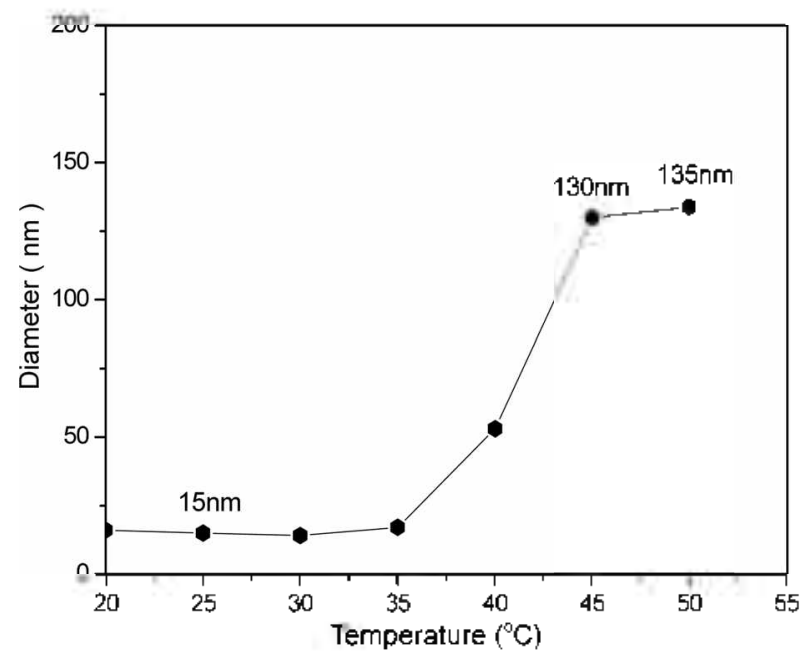

Figure 4. Temperature dependence of particle size of polymer $B$ in water.

Figure 4 shows a representative temperature dependence of the particle size of the polymer B in water. as determined by dynamic light scattering. The diameter began to increase at $35^{\circ} \mathrm{C}$ and grew to about $130 \mathrm{~nm}$ at $45^{\circ} \mathrm{C}$, which suggest the phase separation occurred near LCST, yielding of larger sized nanoparticle. In addition. a plysical gelation. i.e. the sol-gel transition was observed from the concentrated solutions of the same copolymer system. To elucidate the themoresponsive sol-gel transition. the dynamic viscoelastic properties of the $10 \mathrm{wt} \%$ aqueous solutions of polymer were investigated. Figure 5 shows a typical curve on the temperature dependence of storage modulus $\left(\mathrm{G}^{\prime}\right)$ and loss modulus $\left(\mathrm{G}^{\prime \prime}\right)$ for the polymer B with $39 \% \mathrm{LA}$ content. At around 30 " $\mathrm{C}$, both $\mathrm{G}$ ' and $G$ " values increased sharply and the two values became equal at around $45^{\circ} \mathrm{C}\left(\mathrm{G}^{\prime}=\mathrm{G}^{\prime \prime}, \tan \delta=1\right)$. suggesting the phase transition from sol-like to gel-like viscoelastic state. Above $45^{\circ} \mathrm{C}$ the $\mathrm{G}$ value remained higher than $\mathrm{G}^{\prime \prime}$ up to $70^{\circ} \mathrm{C}$. Figure 6 shows the visual demonstration of this sol-gel transition described above.

In summary. we prepared new thermo-responsive poly- 


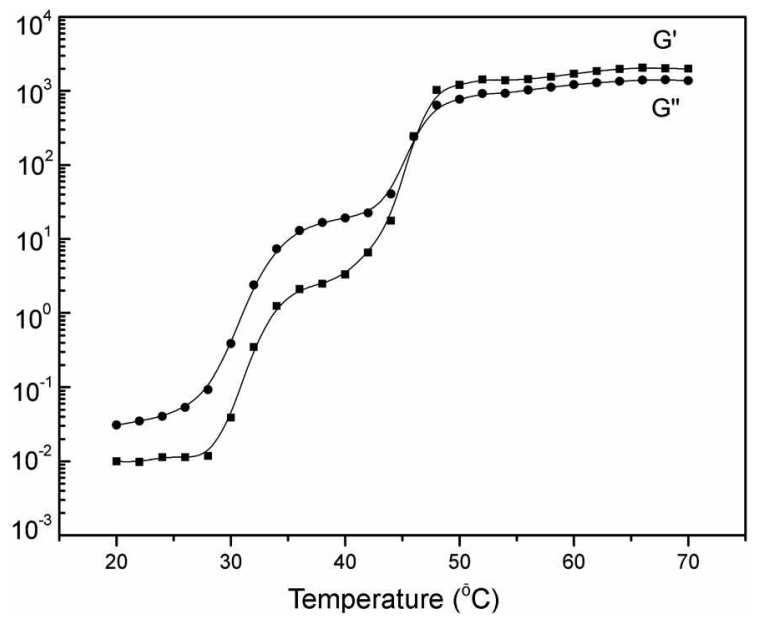

Figure 5. Temperature dependence of storage and loss modulus ( $\mathrm{G}^{\prime}$ and $G ")$ for 10 w $\%$ aqueous solution of polymer $B$.

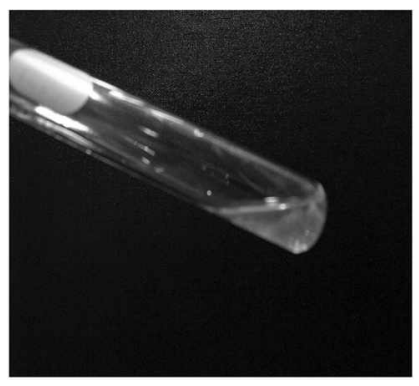

Sol

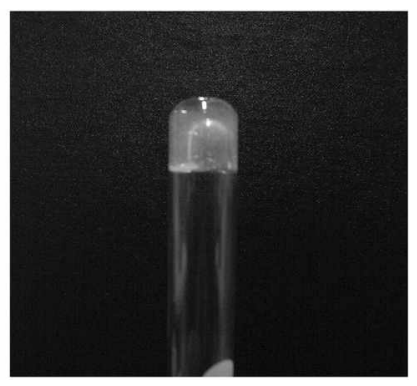

Gel
Figure 6. Photographs of sol-gel transition of amphiphilic PolvAspAin (LANIPEDA). aspartamide derivatives containing $N$-isopropylamine groups. which showed both LCST and sol-gel transition. The phase transition temperature was controllable by changing the content of pendent groups. A combination of different hydrophilic groups and hydrophobic alkyl groups in the side chains can provide thenno-responsive property as the similar results are reported recently, ${ }^{6, y}$ This novel injectable hydrogel system has potential for biomedical applications including tissue engineering and drug delivery șistem.

Acknowledgement. This work was supported by Korea Research Foundation Grant (KRF-2006-005-J04602).

\section{References}

1. Gil. E. S.: Hudson. S. M. Prog. Polmm Sci. 2004. 29.1173.

2. Lee. K. Y.: Mooney. D. T. Chentical Reviews 2001. 101(7). 1869.

3. Caliceti. P.: Quarta. S. M.: Veronese. F. M.: Cavallaro. G.: Pedone. E.: Giammona. G. Biochim. Biophys Acta 2001. 1528. 177.

4. Pitaresi, G.: Pierro. P.: Giammona. G.; Iemma, F.; Muzzalupo, R.; Picei. N. Biomaterial 2004. 25. 4333

5. Castelli, F.: Messina. C.: Craparo, E. F.; Mandracchia. D.; Pitarresi. G. Lrug Delwery 2005. 12.357.

6. Tachibana. Y.: Kurisawa. M.: Uyama. H.: Kakuchi. T.: Kobayashi. S. Chem. Commun. 2003. 106.

7. Kim. J. H: Sim. S. J.: Lee, D. H.: Kim, D.: Lee. Y. K.: Kim. J.-H f. Ind Eng Chem 2004. 10(2). 278.

8. Moon. J. R.: Kim, B. S.: Kim. J.-H. Bull. Koman Chem. So. 2006. 27(7), 981

9. Watanabe. E.: Tomoshige. N. Chent. Lett. 2005. 3+(6). 876.

10. Takeuchi. Y.: Uyama. H.: Tomoshige. N.: Watanabe. E.: Tachibana. Y. J. Pohnt. Sci. Pohnt Chem. 2006. H.671.

11. Neri, P.: Antoni, G: Benvenuti, F: Colola, F; Gazzei, G. J. 1/ed. Chem. 1972, 16,893.

12. Wolk, S. K.: Switt, G.: Paik. Y. H; Yocom. K. M.; Smith. R. L; Simon1. E. S. Hachonolecules 1994. 27. 7613. 